\title{
Resilience to Weather-Related Disasters of a CBFM Community in Ligao, Albay, Philippines
}

\author{
Liezl B. Grefalda ${ }^{1}$, Juan M. Pulhin ${ }^{1,2} \&$ Elsa P. Santos ${ }^{1}$ \\ ${ }^{1}$ Department of Social Forestry and Forest Governance, College of Forestry and Natural Resources, University \\ of the Philippines Los Baños, Philippines \\ ${ }^{2}$ UPLB Interdisciplinary Study Center for Integrated Natural Resources and Environment Management, College \\ of Forestry and Natural Resources, University of the Philippines Los Baños, Philippines \\ Correspondence: Liezl Grefalda, Department of Social Forestry and Forest Governance, College of Forestry and \\ Natural Resources, University of the Philippines Los Baños, Philippines. E-mail: lbgrefalda@up.edu.ph
}

Received: November 14, 2017

Accepted: November 27, 2017

Online Published: December 15, 2017

doi:10.5539/enrr.v8n1p1

URL: https://doi.org/10.5539/enrr.v8n1p1

\begin{abstract}
This study assessed the resilience of a Community-Based Forest Management (CBFM) community in Ligao, Albay, Philippines to weather-related disasters. Resiliency was measured using 38 indicators comprising human, social, natural, financial, and physical capitals. The study used household survey administered to 180 respondents, complemented by focus group discussions (FGD), key informant interviews (KII), and secondary data gathering. Index of five capital assets was calculated using the equation for data normalization by a scale of 0 to 1 . The overall resiliency index was estimated by getting the weighted average of all the capital assets. Pearson Correlation, Chi-square and Spearman Correlation were used to analyze the relationship of age, gender, and household size to the overall resiliency of the community. The CBFM community is less resilient with an index of 0.382 . This was attributed to a lesser access to social and natural capitals with indices of 0.233 and 0.244 , respectively. However, the CBFM program remains a promising strategy in improving the adaptive capacity of upland communities by contributing to the enhancement of their social and natural assets. Results revealed that there is a positive correlation between household size and resiliency while age and gender were not correlated. To build resiliency, it is recommended to increase community capacity through education and skills development, ensure access to services, provide technical and financial support from the government and promote collaboration among various stakeholders.
\end{abstract}

Keywords: capital assets, community-based forest management, resilience, weather-related disaster

\section{Introduction}

Climate change is indisputable as exhibited by gradual changes in mean temperature and precipitation patterns, sea level rise, increased frequency of extreme weather-related events, and potentially catastrophic transformations of ecosystems (IPCC, 2007). These changes will increase the probability of extreme weather events which may be associated either with high precipitation (i.e., storms, flood and landslides) or with low precipitation (i.e., drought, heat and wildfire) (Keim, 2008). Climate change will also lead to greater exposure and sensitivity of rural populations through three major impacts on their livelihoods: increase in environmental risks, reduction in livelihoods opportunities, and in consequence, greater stresses on existing social institutions (Agrawal, 2008).

The Philippines is located in the western rim of the Pacific ring of fires and typhoon belt, thus it is naturally vulnerable to various natural hazards such as earthquake, volcanic eruption, drought, tidal wave, landslide, flood, and tropical cyclones (Uy et al., 2010). Several studies in the Philippines reveal that climate variability and extreme event occurrences have increased in recent years. The country continuously faces the threat of extreme events as identified in the Climate Risk Index (CRI) (Harmeling, 2009).

Every year, an average of 20 typhoons pass the country and about two to three destructive typhoons center on the Bicol region (PAGASA, 2016). Albay is one of the provinces in Bicol most affected by typhoons, being bounded by the Pacific Ocean on the East, Samar Sea on the Southeast, and Sibuyan Sea on the Southwest. Albay has 16\% frequency probability of experiencing destructive typhoons due to its location (Uy et al., 2010). One of the worst typhoons that the province experienced was Typhoon Durian (locally named Reming) in November 2006. The 
disaster affected 1,060,785 people and damaged properties at about USD 71,787,460 (APSEMO, 2010). The increasing frequency of strong typhoons like Reming, together with the worldwide evidence of climate change impacts, illustrate that local communities are becoming more vulnerable to climate-related hazards. Aside from typhoons, Albay may be affected by other climate change events such as sea level rise, increased rainfall, and warmer temperatures.

Those who suffer most from the impacts of disasters are the socially disadvantaged groups, very poor households, and natural resource-dependent communities (Agrawal, 2008). It is therefore imperative for societies and communities dependent on natural resources to enhance their adaptive capacity to the impacts of disasters, particularly when such impacts lie outside their experienced coping range (Tompkin \& Adger, 2004). Thus, to minimize or reduce the impacts of disasters, the community has to be in a resilient state.

Resilience is the ability of groups or communities to adapt in the face of external social, political, or environmental stresses and disturbances (Adger, 2000). To be resilient, societies must generally demonstrate the ability to: (1) buffer disturbance, (2) self-organize, and (3) learn and adapt (Trosper, 2002). Adaptive capacity, which is refers to the set of preconditions that enables individuals or groups to respond to climate change (Olsson \& Folke 2001; Brooks 2003; and Berkhout et al., 2004), has been associated with many characteristics of resilience. Resilience can be seen in responses to rapid changes in environmental conditions, especially in response to natural hazards (Berke et al. 1993; Berke \& Beatley, 1997).

Five distinct dimensions encompassing resilience can be based on the notion of capitals, namely human, social, financial, physical, and natural (Mayunga, 2007). These dimensions and indicators present a quantifiable measurement of community resiliency which can be applied to determine the level of resiliency of a forest-dependent community. On the other hand, resiliency as a process-oriented concept and having a notion of adaptation can also be attributed to supportive policies (Manyena, 2006) and strengthened local institutions.

Community-Based Forest Management (CBFM) as a development strategy in the uplands areas in the Philippines envisions to empower people's organizations (PO) and assist them in attaining sustainable management of forestlands and ancestral domains. This is achieved through effective partnership with support group such as the Department of Environment and Natural Resources (DENR), Local Government Units (LGUs), Non-Government Organizations (NGOs) and other mandated agencies and their instrumentalities (DENR-FMB, 2008). However, the achievement of CBFM vision is hardly realized as the program faces continuing challenges, the latest of which is brought by disasters.

By virtue of Executive Order 263, CBFM was adopted as the national strategy to ensure the sustainable development of the country's forestland resources. However, the central problem of sustainable development is how to order society to simultaneously increase social resilience and ecological resilience (Harrison, 2000). Many researches on resilience focused on ecological resilience while the social dimension is somewhat overlooked (Harrison, 2000). Losses from climate extremes such as landslides, droughts and other climate- and weather-related phenomena have risen in recent decades (JRC/IES et al., 2009). The responses to such impacts and variability have to be determined locally and collectively (IPCC Fourth Assessment Report, 2007). As emphasized by Uy (2010), local actors are critical in achieving real impact on the ground as adaptation is highly site-specific.

While there has been an increasing interest in studying vulnerability and adaptation practices of local communities in the Philippine uplands in relation to climate variability and change (see for instance Pulhin et al., 2008, Peras et al. 2008, and Tapia et al., 2014) there is a big gap in understanding the resilience of upland communities to weather-related disasters. Albay was seriously affected by the disaster caused by Typhoon Reming in 2006 (Uy et al., 2011). In general, Albay is considered a high-risk province due to hazards caused by volcanic eruptions, landslides, earthquakes, floods and typhoons. This study therefore assessed the resiliency of a forest-dependent community in the Philippines to the impacts of weather-related disasters by examining a CBFM community in the municipality of Ligao, province of Albay in the Philippines. Specifically, it identified and described the different weather-related disasters in the study area; determined the impacts of the weather-related disasters to the community especially on livelihood, income, health, agriculture, forest, water and infrastructure; assessed the level of resilience to weather-related disasters of the CBFM community and the factors associated with resilience; and analyzed the implications of the findings in enhancing community resilience. 


\section{Research Method}

\subsection{The Study Site}

Albay province, which covers the municipality of Ligao, is one of the most vulnerable provinces in the Philippines. Based on the study conducted by Manila Observatory (2005), Albay was identified as the top province most vulnerable to combined climate and weather-related risks such as typhoons and projected rainfall change. The study was conducted in a CBFM area in Barangay Maonon, Ligao, Albay located southwest of Ligao (Figure 1). It has a total land area of 2, 493.57 hectares. The barangay is 12 kilometers away from the national highway. Maonon belongs to Climatic Type 3 which has a short dry season lasting from one to three months while heavy rainfall occurs from July to November.

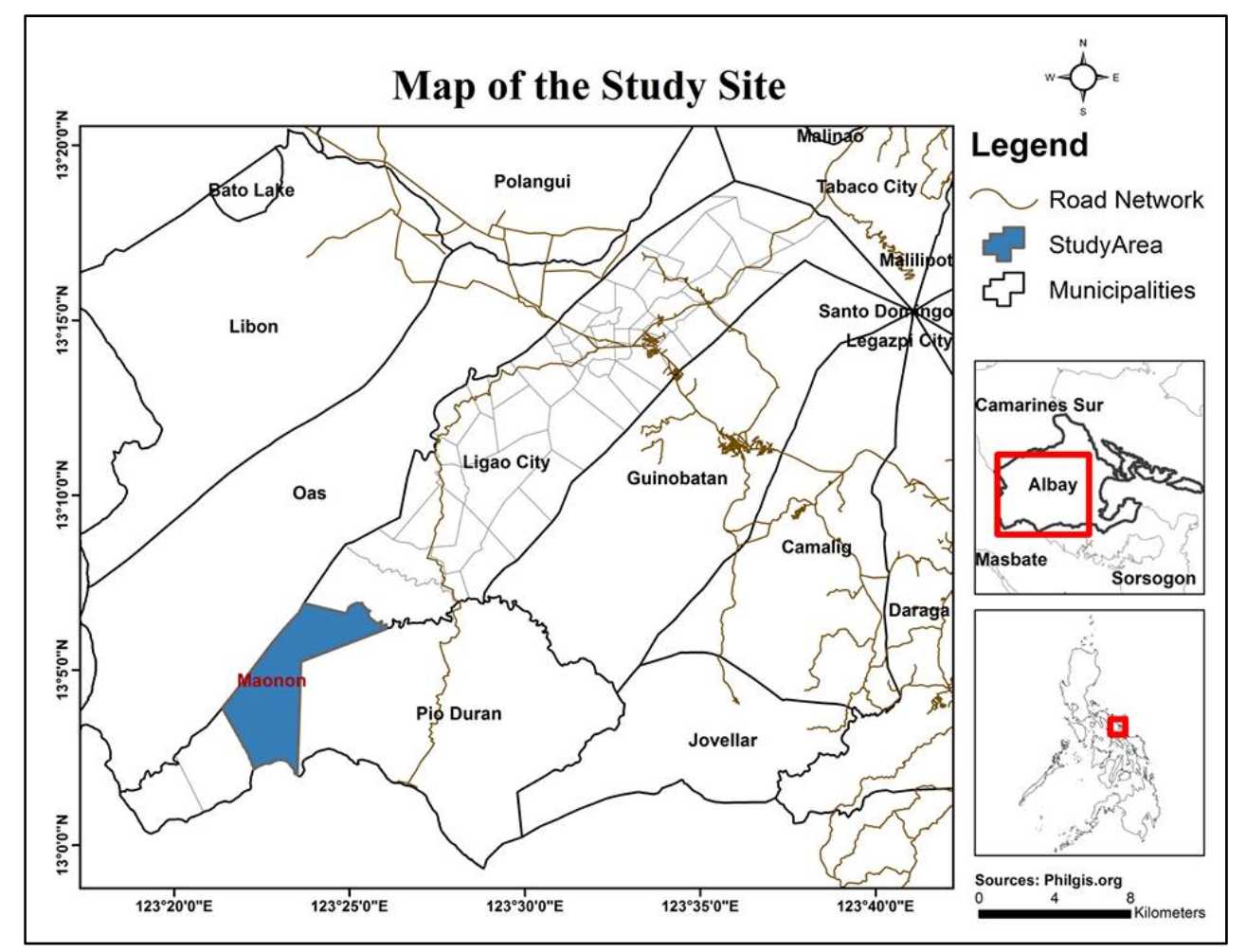

Figure 1. Map of Ligao, Albay, Philippines. Barangay Maonon is located at the south western part of the city. The CBFM area awarded to PO Maonon Upland Planters Association is located at $13^{\circ} 2^{\prime} 30^{\prime \prime} \mathrm{N} 123^{\circ} 20^{\prime} 26^{\prime \prime} \mathrm{E}$

\subsection{Data Collection and Analysis}

The study was done from 2011 until 2014. Primary and secondary data were collected using several data collection procedures such as surveys, key informant interviews (KIIs) and Focus Group Discussions (FGD). Study respondents were Barangay Maonon residents, either members or non-members of the CBFM People's Organization (PO), cultivating in the upland area and willing to participate in group discussions. Of the 596 households recorded in 2011, 180 households were chosen as sample size using the Cochran formula (1977) as well as the correction formula and table developed by Bartlett, Kotrlik and Higgins (2001).

Officials of the local government and national agencies were selected for the KIIs. FGD with the CBFM community was also conducted to obtain the community's level of information on major disasters attributed to weather-related hazards; impacts of hazards/disasters to livelihood, income, health, agriculture, forest, water and infrastructure; identification of adaptive strategies; and options for building/enhancing community resilience to disasters. It was attended by members of community including the leaders/barangay officials, elders and CBFM PO members.

Secondary data were collected from various institutions/agencies such as the PO, DENR-FMB, Provincial Environment and Natural Resources Office (PENRO), Community Environment and Natural Resources Office (CENRO), Centre for Initiatives and Research on Climate Adaptation (CIRCA), LGU-ENRO, Barangay Council, 
and Provincial Disaster Risk Reduction and Management Council (PDRRMC). Climatic information such as climate type, El Niño and La Niña episodes, and average monthly temperature were obtained from Philippine Atmospheric, Geophysical and Astronomical Services Administration (PAGASA). Municipal profile, land-use and topography were gathered from the Municipal Planning and Development Office (MPDO) while socio-demographic statistics was sourced from the National Statistics Office (NSO). Secondary data were gathered before and during the study period. Updates on some information were collected until January 2016.

Since resilience is a multidimensional concept, proxy indicators were used. In addition, five capital assets (human, social, financial, natural and physical) and indicators were used to assess the resiliency of the CBFM community to weather-related disasters (Table 1).

Table 1. Forms of capital and its indicators.

\begin{tabular}{|c|c|c|}
\hline Forms of Capital & Indicators & Explanation of Indicators \\
\hline \multirow[t]{4}{*}{ Human Capital } & Education & Highest educational attainment, educational attainment of family members \\
\hline & Skills & Diversity of skills of household members \\
\hline & Health & $\begin{array}{l}\text { Access to health facility: availability of health facility, distance to health } \\
\text { facilities, availability of medicines }\end{array}$ \\
\hline & Dependence Ratio & $\begin{array}{l}\text { The ratio of the household under } 18 \text { and over } 65 \text { years of age to the population } \\
\text { between } 19 \text { and } 64 \text { years of age }\end{array}$ \\
\hline \multirow[t]{5}{*}{ Social Capital } & Membership in & Number of organizations affiliated with \\
\hline & organizations & No. of years in the organization \\
\hline & Social network & Distance from nearest relative \\
\hline & Leadership & Affiliation with local political body \\
\hline & Institutional support & $\begin{array}{l}\text { Number of institutions that provide assistance in order to minimize impacts of } \\
\text { disasters }\end{array}$ \\
\hline \multirow[t]{2}{*}{ Financial Capital } & Livelihood & Sources of income of the households \\
\hline & Income & Average household monthly income and diversity of income \\
\hline \multirow[t]{5}{*}{ Natural Capital } & Farm size & Area of utilized farmland \\
\hline & Soil quality & Soil fertility \\
\hline & Production & Yield and diversity of crops produced \\
\hline & Potable water & Availability of running water in the household \\
\hline & Water source & Distance from the nearest water source \\
\hline \multirow[t]{8}{*}{ Physical Capital } & Assets & Ownership of land, house, and other household assets \\
\hline & Farm machines & Availability of and access to farm production equipment \\
\hline & Storage facility & Availability of and access to grains storage facility, quantity of grains stored \\
\hline & Reservoir/ irrigation facility & Availability of and access to water reservoir and irrigation facility \\
\hline & Communication facility & Availability and access to communication facility \\
\hline & Early warning devices & Availability and functionality of early warning devices \\
\hline & Road/ Mobility & House and farm distance to main road \\
\hline & Energy/ Electricity & Presence/absence of electricity in the household \\
\hline
\end{tabular}

Descriptive statistics such as the mean, frequency counts and percentage were used to describe the respondents' characteristics and resilience indicators. Relationship between demographic variables (i.e., age, gender and household size) and social resiliency was measured using Pearson Correlation, Spearman Correlation and Pearson Chi-Square Test.

\section{Results and Discussion}

\subsection{Livelihood and Income Sources}

The major sources of livelihood of the community were farming and fishing (Figure 2). Majority of the respondents $(96.7 \%)$ relied on farming as source of income, followed by fishing $(63.9 \%)$. Other sources of income included livestock raising (38.9\%) labor/manpower (21.2\%), sewing (6.7\%), employment (6.1\%), remittance $(6.1 \%)$, trading/vending $(5.6 \%)$ and pension $(1.1 \%)$. Findings imply that farming and fishing are both weather-dependent, making community livelihood more vulnerable.

Table 2 shows that the respondents' mean monthly income was PhP 3,845.83, including proceeds from off-farm sources. For households, the mean monthly farm income was PhP 2,148.36. When compared to the 2012 records 
of the Philippine Statistics Authority (PSA), the mean monthly income of respondents were relatively lower. The average annual per capita poverty threshold in Bicol region is PhP 18,257.00. Hence, a Bicolano family with five members needs PhP 7,607 a month or about PhP 91,285 annually. Bicolano refers to a Filipino ethnic group who lives in the Bicol region, the southeastern peninsula of Luzon island.

Most of the households' income $(87.22 \%)$ were insufficient to provide for the needs of the family as shown in Table 3. Only $12.88 \%$ perceived that their income was sufficient and no one responded to have more than sufficient income. Based on the Bicol regional development plan (2016), 45.1\% of the Bicolanos are poor. They earn below the minimum amount required for food and other basic needs. Most families obtain income from agriculture, forestry and fishery sectors. The magnitude, frequency and severity of hazards such as typhoons and other extreme weather events may have affected the productivity of the land, resulting to losses in livelihood, assets and income. Hence, insufficient income can be attributed to low productivity of farming per hectare and lack of fish catch especially during extreme events exacerbates the household's income state.

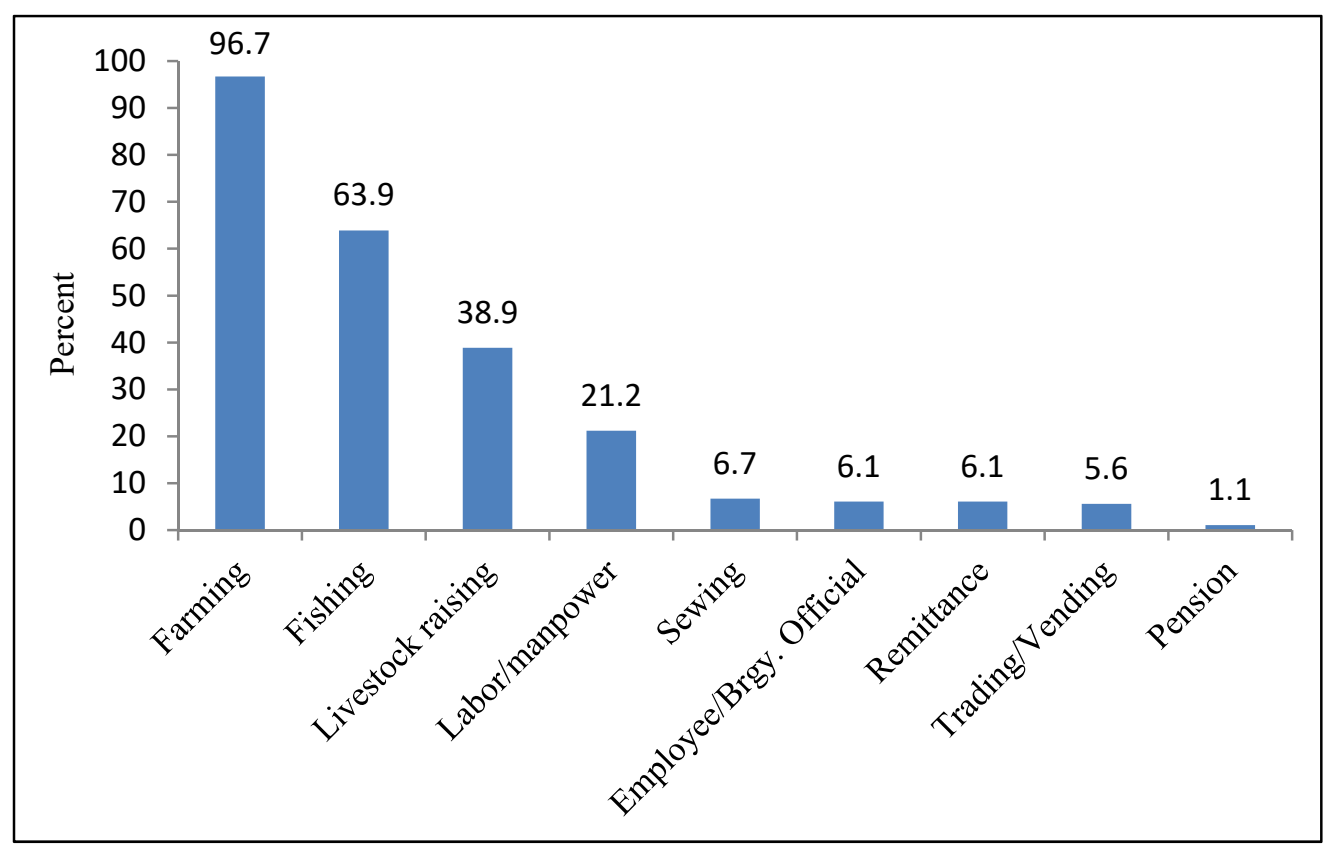

Figure 2. Income sources of the respondents.

Table 2. Summary of total farm income of the respondents per month.

\begin{tabular}{lcc}
\hline Descriptive Statistics & Mean & Standard Deviation \\
\hline Total income $(\mathrm{PhP})$ & $3,845.83$ & $2,148.36$ \\
Farm income $(\mathrm{PhP})$ & $2,947.22$ & $1,682.76$ \\
\hline
\end{tabular}

Table 3. Sufficiency of income of the households.

\begin{tabular}{lccc}
\hline & Income Sufficiency & Frequency & Percent \\
\hline Sufficient & 23 & 12.78 \\
Insufficient & 157 & 87.22 \\
Total & 180 & 100.00 \\
\hline
\end{tabular}

\subsection{Agricultural Practices}

May and October are the cropping seasons in the study area. Rice and corn were the major crops planted and that farms were mainly rainfed. Rice was planted either on plains or upland areas. Monocropping, particularly with rice and corn and intercropping of upland rice, banana and taro ( $g a b i)$, were the common agricultural techniques used. These farming techniques assure availability of food for both households and community. 
The community is one of the beneficiaries of the Community Farming Village (CFV). CFV is a technology/program aimed at sustainable upland farming. It addresses flooding and soil erosion in upland farms as these cause extensive damages especially during typhoons and rainy seasons (Espinas, 2013).

\subsection{Extreme Events and Disaster Experienced by the Community}

Community members identified past occurrences of weather-related disasters through FGD and household survey (Table 4). The dates of occurrences mentioned by the participants were validated with PAGASA records. There were lapses with the actual disaster dates although the observed impacts were recalled in detail by the respondents.

Table 6 presents the weather extremes causing disasters that have greatly affected the community, namely prolonged rainy season (La Niña), prolonged drought (El Niño) and strong typhoons. Three strong typhoons (i.e. Reming (Durian), Yolanda (Haiyan), Nina (Nock-ten) categorized by PAGASA to cause major destruction in the country passed through Ligao.

The historical El Niño and La Niña episodes from 1951 to 2016 is shown in Table 5. The El Niño periods identified by the respondents accurately fit in this record as indicated by the Oceanic Niño Index (ONI). The ONI refers to the measure of the departure of three-month average sea surface temperature from the 30 -year average (NOAA Climate Services 2009). El Niño episodes in 1997-1998, 2015-2016 and 1982-1983 had the highest departure at 2.5 and 2.3, respectively. This indicates that the most intense El Niño episodes in the country were recalled by the respondents.

A compilation of the 20 most intense typhoons in the Bicol region between 1967 to 2016 were recalled by the respondents (Table 6). The range of wind speed was from 180-320 kilometers per hour ( $\mathrm{km} / \mathrm{hr})$. Among the recorded typhoons, Typhoon Reming (Durian) which happened in 2006 has the most devastating wind power. Based on PAGASA Legazpi City Station, it poured $566 \mathrm{~mm}$ of rain in just 12 hours.

Table 4. Weather extremes experienced in the community.

\begin{tabular}{|c|c|c|c|}
\hline $\begin{array}{l}\text { Weather } \\
\text { Extremes }\end{array}$ & $\begin{array}{c}\text { Local } \\
\text { Observations }\end{array}$ & $\begin{array}{l}\text { PAGASA } \\
\text { Official Record }\end{array}$ & Community Observations \\
\hline Prolonged & 1989 & 1989 & Flooding; pest and diseases to crops \\
\hline rainy season & 1995 & 1996 & \\
\hline \multirow[t]{2}{*}{ (La Niña) } & 2008 & 2008 & \\
\hline & 2010 & $2010-2011$ & \\
\hline Prolonged & 1987 & 1986-1987 & Damaged crops; decreased in crop yield, rivers dried up; \\
\hline drought & 1994 & 1993-1994 & limited access to irrigation \\
\hline \multirow[t]{2}{*}{ (El Niño) } & $1997-1998$ & $1997-1998$ & \\
\hline & $2015-2016$ & $2015-2016$ & \\
\hline Strong & 1970s - Sening & 1970s - Sening* & Affected coconut plantations, abaca, rice harvest and \\
\hline \multirow[t]{12}{*}{ Typhoons } & & & $\begin{array}{l}\text { vegetables; massive damage to homes and schools; strong } \\
\text { wind }\end{array}$ \\
\hline & 1980s - Sisang & 1987 - Sisang* & damaged crops, strong wind; \\
\hline & September 2006 & September 2006 & Flooding; landslide \\
\hline & Milenyo & Milenyo & \\
\hline & $\begin{array}{l}\text { November } 2006- \\
\text { Reming }\end{array}$ & November 2006 - Reming* & $\begin{array}{l}\text { Widening of riverbeds; landslide/mudslide; damaged road and } \\
\text { bridges; fatalities, loss of livelihood; income loss }\end{array}$ \\
\hline & 2009 - Ondoy & 2009 - Ondoy & Flooding; landslide \\
\hline & 2011 - Juaning & 2011 - Juaning & Road destruction; flooding; landslide \\
\hline & 2013 - Yolanda & 2013 - Yolanda & Flooding, landslides; damage to agriculture and infrastructure \\
\hline & 2014 - Glenda & 2014 - Glenda & Damaged houses \\
\hline & & & Damage to agriculture and infrastructure \\
\hline & & & Power interruption \\
\hline & 2016 - Nina & 2016 - Nina & $\begin{array}{c}\text { Displaced families; damaged houses; Power interruption; road } \\
\text { and bridges are impassable; damage to agriculture and }\end{array}$ \\
\hline
\end{tabular}




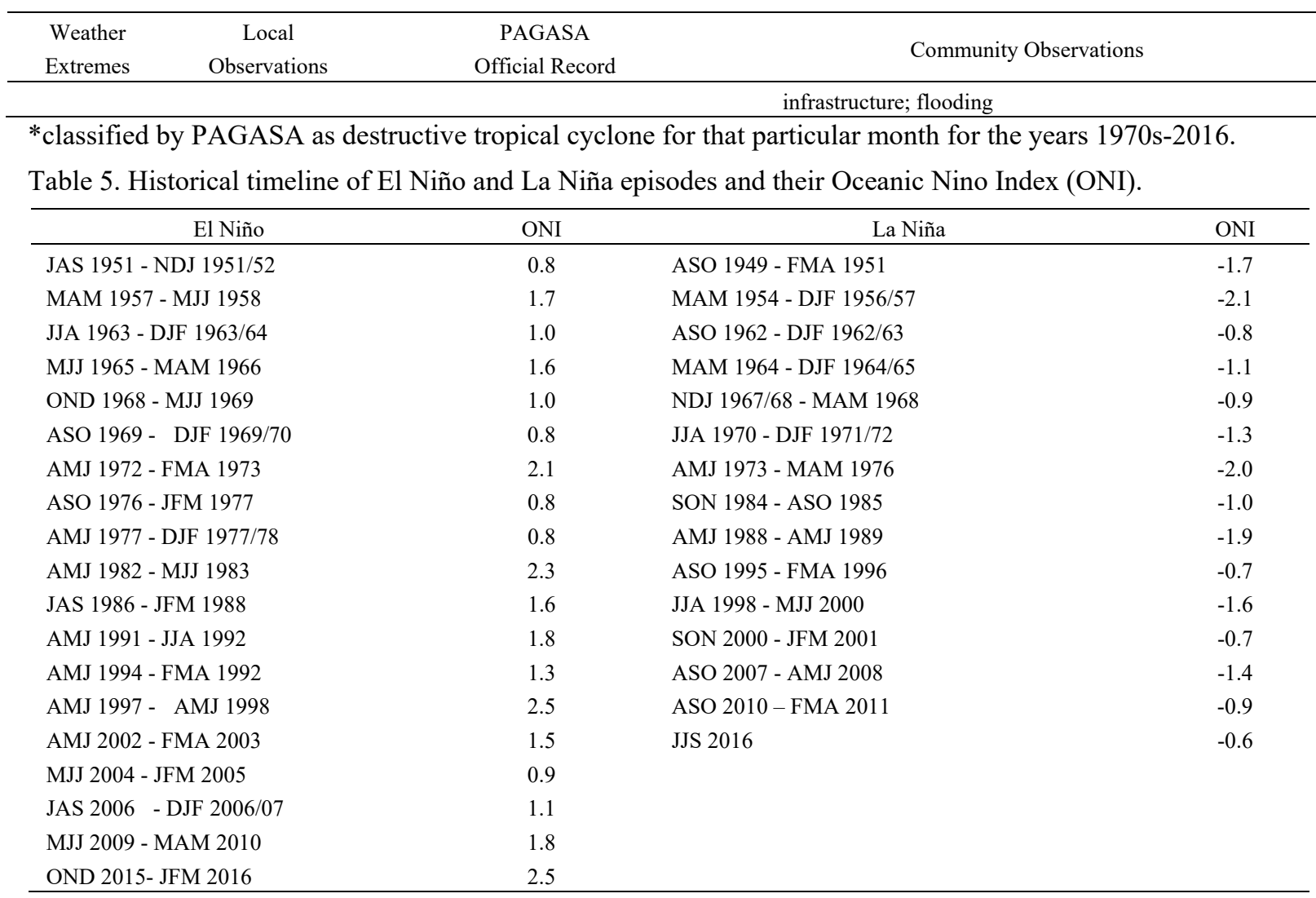

Source: PAG-ASA, Legazpi City.

Table 6. Twenty most intense typhoons of Bicol Region, Philippines (1960-2016)

\begin{tabular}{clllc}
\hline No. & Name & International Name & \multicolumn{1}{c}{ Period Of Occurrences } & Highest Wind Speed $(\mathrm{km} / \mathrm{hr})$ \\
\hline 1 & Reming & Durian & November 26-December 1, 2006 & 320 \\
2 & Yolanda & Haiyan & November 7-9, 2013 & 315 \\
3 & Nina & Nock-ten & December 24-27, 2016 & 290 \\
4 & Sening & Joan & October 11-15, 1970 & 275 \\
5 & Rosing & Angela & October 30-November 4, 1995 & 260 \\
6 & Anding & Irma & November 21-27, 1981 & 260 \\
7 & Glenda & Rammasun & July 13-17, 2016 & 259 \\
8 & Loleng & Babs & October 15-24, 1998 & 250 \\
9 & Yayang & Vera & November 4-7, 1979 & 240 \\
10 & Sisang & Roger & November 23-27, 1987 & 240 \\
10 & Herming & Betty & August 7-14, 1987 & 240 \\
12 & Saling & Dot & October 15-20,1985 & 240 \\
13 & Unsang & Ruby & October 21-26, 1988 & 215 \\
14 & Warling & Tip & November 17-27, 1983 & 205 \\
15 & Welming & Emma & October 31-November 8, 1967 & 205 \\
16 & Yoling & Patsy & November 17-20,1970 & 200 \\
17 & Kading & Rita & October 25-27, 1978 & 185 \\
18 & Huaning & Haitang & June 22-July 2, 1976 & 185 \\
19 & Dindo & Nida & May 13-19, 2004 & 185 \\
20 & Milenyo & Xangsane & September 25-30, 2006 & 180 \\
\hline
\end{tabular}

Source: PAGASA, Legazpi City.

\subsection{Impacts of Weather-Related Disasters}


Table 7 shows the different impacts of weather extremes, typhoon, El Niño and La Niña, focusing on livelihood/income, health, agriculture, water, forest and infrastructure of the local community. The most affected sector was the community's livelihood and infrastructure. In terms of farming impacts, the above-mentioned weather-extreme events caused destruction and loss of harvest through direct effect of strong winds, high temperature, intense rains, and flooding. Based on the survey, majority of the household migrated to the city to work as laborers or look for other jobs. A research conducted by Uy (2011) in Bacacay, Albay emphasized that majority of the community members articulated that their livelihoods are mostly affected by climate or weather extremes. The impact is well substantiated because agriculture and forestry sectors are climate or weather-sensitive. Empirical evidence from all regions of the world shows that disasters produce measureable declines in income, which is disproportionally concentrated in poor households and communities (World Bank, 2010).

In relation to the health sector, contagious diseases, injured community members and fatalities or loss of lives are among the disastrous results of strong typhoons. Water was also a problem during El Niño because the river dries up and the farmers have limited access to irrigation. Upland areas or forests experienced soil erosion and landslides during typhoons, and drought or cracked soil during El Niño.

Typhoons affect infrastructure, particularly damaging houses in both upland and coastal communities as these are mostly built with light materials. Household assets and belongings are often washed away by floodwaters. Roads are also destroyed, causing transportation problems.

Disaster impacts depend on magnitude and extent. The notable disaster that struck the Philippines was Typhoon Yolanda, which made landfall on November 8, 2013 (NDRRMC, 2013). Yolanda sustained winds of 270 kilometer per hour (kph), gustiness of up to $312 \mathrm{kph}$, and a storm surge as high as 7 meters. The provinces of Leyte and Samar were worst hit and this resulted to 6,155 dead, 28,626 injured, and 1,785 missing (NDRRMC Situation Report, 2013). The total damage cost is PhP 36,690,882,497.27, which covers damages to infrastructure and agriculture. In addition to this, water supply and communication facilities were destroyed. In the study area, the disaster impacts experienced by the community differed from Leyte and Samar because of the difference in typhoon intensity.

Table 7. Summary of impacts of weather-related disasters to the community.

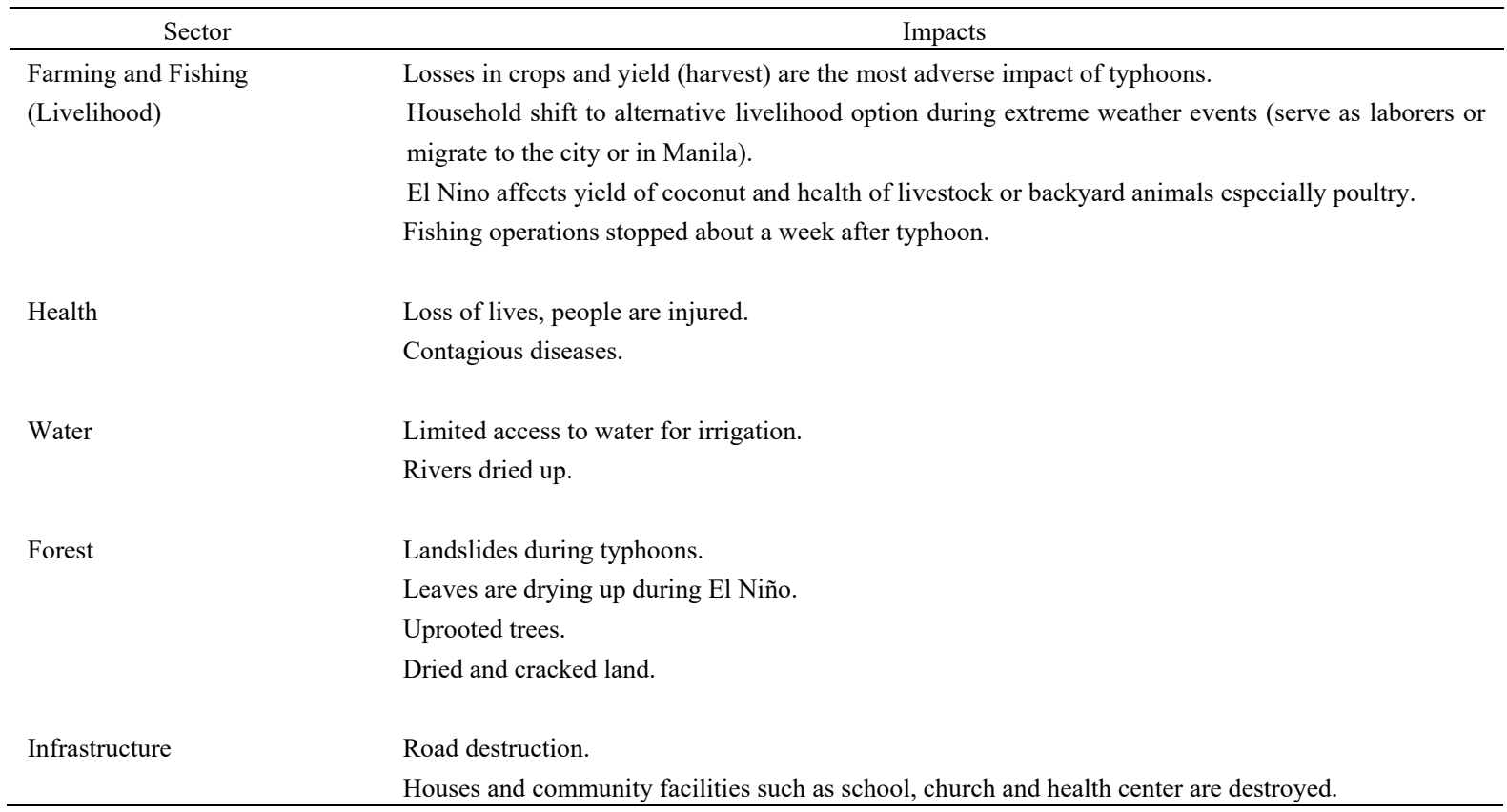

\subsection{Resiliency Index}

The resiliency index, composed of human, social, natural, financial and physical capital assets, was identified using the data obtained from the household survey. The index of each indicator was computed using the equation for data normalization and then the average index for each capital asset was generated. Overall resiliency index was computed by getting the average results of each capital asset. The value for the resiliency index and the 
capital asset could range from 0 to 1 , with 1 being the highest, indicating highest access to a particular capital asset while 0 indicating no access at all. Resulting values of indexed sub-components, the five capitals of Barangay Maonon are presented in Table 8.

Table 8. Resiliency index of five capital assets and its indicators

\begin{tabular}{|c|c|c|c|}
\hline Major Component & Index & Sub-component & Index \\
\hline \multirow[t]{7}{*}{ Human Capital } & 0.376 & Respondents' educational attainment & 0.153 \\
\hline & & Highest educational attainment of household member & 0.431 \\
\hline & & Dependency ratio & 0.355 \\
\hline & & Skill & 0.346 \\
\hline & & Health & 1.000 \\
\hline & & Distance to health facility & 0.280 \\
\hline & & Access to medicine & 0.067 \\
\hline \multirow[t]{6}{*}{ Social Capital } & 0.233 & Membership in the organization & 0.300 \\
\hline & & Years in the organization & 0.173 \\
\hline & & Distance of nearest relative & 0.064 \\
\hline & & Affiliation with local political body & 0.107 \\
\hline & & Number of years in the council & 0.043 \\
\hline & & Institutions providing assistance & 0.710 \\
\hline \multirow[t]{6}{*}{ Natural Capital } & 0.244 & Area of utilized farm & 0.152 \\
\hline & & Yield & 0.229 \\
\hline & & Diversity of crops & 0.303 \\
\hline & & Number of animals raised & 0.393 \\
\hline & & Distance of the house from water source & 0.219 \\
\hline & & Distance of the farm from the nearest water source & 0.086 \\
\hline \multirow[t]{3}{*}{ Financial Capital } & 0.443 & Farming income & 0.326 \\
\hline & & Total income & 0.316 \\
\hline & & Diversity of income sources & 0.686 \\
\hline \multirow[t]{16}{*}{ Physical Capital } & 0.626 & Ownership of land (house) & 1.000 \\
\hline & & Ownership of land (farm) & 0.956 \\
\hline & & Tenure type (house) & 1.000 \\
\hline & & House floor area & 0.632 \\
\hline & & Lot area & 0.399 \\
\hline & & House structure & 0.494 \\
\hline & & No of assets owned & 0.408 \\
\hline & & No of equipment owned & 0.778 \\
\hline & & Storage facility & 0.267 \\
\hline & & Milling facility & 0.944 \\
\hline & & Availability of water reservoir for irrigation & 0.944 \\
\hline & & Source of potable water & 0.228 \\
\hline & & Distance of house to road & 0.273 \\
\hline & & Distance of farm to road & 0.511 \\
\hline & & Electricity in the household & 0.678 \\
\hline & & No of hours with electricity & 0.506 \\
\hline $\begin{array}{l}\text { Overall Resilience } \\
\text { Index }\end{array}$ & 0.382 & & \\
\hline
\end{tabular}


The five capital assets or the so-called community capitals have been used to measure community resilience to disasters. Resilience index of the community was illustrated in a web diagram of the five capital assets (Figure 3). The center point of the diagram means zero access to the assets while the outer point means higher access or ownership. Based on Chuku and Okoye (2009), higher index and the more varied the asset base indicate greater system's adaptive capacity and potential for sustainability. As shown in the diagram, the highest point obtained was 0.626 while the lowest is 0.233 .

The diagram implies average access to financial capitals $(0.443)$ while nearly average access to human capital (0.376). However, they have very low access to social and natural capitals $(0.233$ and 0.244$)$, while above average access to physical capitals $(0.626)$.The overall resilience value of 0.382 represents the average numeral representation of the actual situation in the communities. This value showed lower resiliency, aggravated by weather-related hazards.

The community scored lowest in terms of human capital. The community has its own health center but the supply of medicine is limited. In worst cases, some community members were not able to get medicine from the health center. The highest educational level obtained by most respondents is elementary education. However, the collective educational level of the households has a higher value $(0.431)$. Dependency ratio was also low, which indicates more number of dependents attributed to lower age range of respondents in the community. Skills of the household head were below middle value (0.346). Aside from farming, some respondents have at most two additional skills that enabled them to supplement their income such as laborer/construction worker, driving and weaving. Based on the study by Smith (2001), human capital is a vital asset, which is an advantage of the community to cope, adapt and recover from disasters. Human capital is innate, derived and accumulated in the working-age population, which could be helpful in sustaining economic or financial aspect of the community. Human capital, which includes education, skills and health, is the most important determinant of resilience among others because it is innate to individuals. Whatever disasters that may happen, if an individual or the community as a whole had an adequate human capital, the capacity to cope and recover would be greater. Thus, the more human capital available in the community, the higher the capacity for building resilience.

The physical capital of the community is strengthened by the type of ownership of farm lands and houses as well as the lot where their houses are built. The physical capital is present but access such as water source is very low. Water for domestic use and irrigation was one of the problems in the area as mentioned during the FGD. Physical structures are critical for improving resilience of a community and these include water system, transportation, electricity and communication facilities. After natural hazards, disaster happens when these built services are disrupted. However, the number of built assets would not be enough to measure the resiliency of the physical capital. Access to these assets and the manner by which a community resumes the physical assets in the aftermath of disaster would influence the extent of recovery.

In terms of financial capital, diversity of income sources slightly increased. However, this does not guarantee resiliency in terms of financial capital because based on the results of livelihood diversity per household, each household had at most four sources of income/livelihood. The community may have an average index in terms of financial capital, but this does not guarantee fast recovery after a disaster. According to Buckle (2001), stable and growing economy will generally enhance resilience, while an unhealthy or declining economy is an indicator of increasing vulnerability. Thus, there is a need to enhance financial capital of the community to build its resilience to disasters.

Social capital got the lowest score among the five capital assets. This was attributed to the limited affiliations in the political body as well as the number of years of involvement in the council. Putnam (1995) defines the concept of social capital as features of social organization such as networks, norms, and social trust that facilitate coordination and cooperation for mutual benefit. The result reflects that the level of trust and norms in the community is low. A community with a low social capital has less capacity to cope or difficulty in disaster recovery, thus making them less resilient. According to Davidson (2006) the most resilient communities are those that work together toward a common goal.

Natural capital was also low and affected by the lowest score obtained in terms of proximity of farm to the water source. Assessment of the natural capital included land area, yield or harvest, animal raised and water source. The average area of utilized farms for every household was about 1.5 hectares, which also corresponded to low index and lower value of natural capital. Potable water was also a problem in the study area. In addition to this, there were few forest trees found in the CBFM area such as rain tree (Samanea saman), teak (Tectonia grandis), gmelina (Gmelina arborea), mahogany (Sweitenia macrophylla) and narra (Pterocapus indicus) which are part of the reforestation project in the late 1990s (DENR reports, n.d.). In the context of disaster resilience, natural 
resources such as vegetation cover play an important role in protecting upland areas from weather-related hazards such as typhoon and floods. The presence of CBFM in the area does not contribute well in the improvement of the community's natural capital.

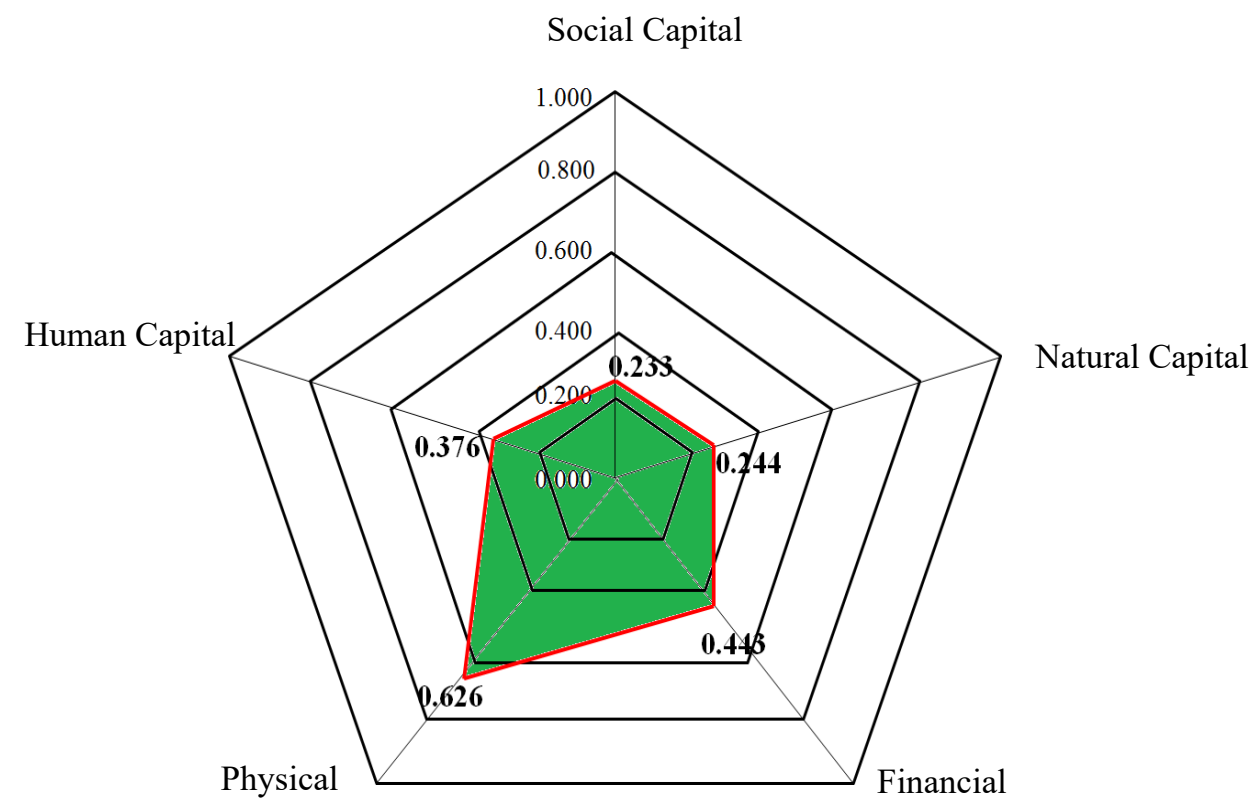

Figure 3. Web diagram of the five capital assets in Barangay Maonon

\subsection{Relationship between the Hypothesized Factors and Resiliency Indices}

In this study, three independent variables were assumed to influence resiliency: age, gender of the household head, and household size. The relationship of these variables to resilience was determined using the Statistical Package for Social Sciences (SPSS) program.

The data was run first with SPSS for standardization, which uses Shapiro-Wilk Test. This test is appropriate for small sample sizes $(<50$ samples), but can also handle sample sizes as large as 2000 . For this reason, the researcher used the Shapiro-Wilk test as the numerical means of assessing normality. The Shapiro-Wilk test result showed that the p-values for resilience (0.304) and age (1.910) were greater than 0.05 level of significance, therefore the data followed a normal distribution (Table 9). On the other hand, the p-values of gender $(0.000)$ and household size $(0.000)$ were less than the said p-value, thus it did not follow a normal distribution.

Table 9. Shapiro-Wilk Test of normality for resiliency, age, gender and household size.

\begin{tabular}{lcccc}
\hline \multirow{2}{*}{ Variable } & \multicolumn{3}{c}{ Shapiro-Wilk } & \multirow{2}{*}{ Conclusion } \\
\cline { 2 - 4 } & Statistic & Df & Sig. & Normal \\
Age & 0.989 & 180 & $0.191^{\text {ns }}$ & Not normal \\
Gender & 0.623 & 180 & $0.000^{*}$ & Not normal \\
Household size & 0.964 & 180 & $0.000^{*}$ & Normal \\
Resilience & 0.991 & 180 & $0.304^{\text {ns }}$ & \\
\hline
\end{tabular}

* significant at $5 \%$ level of alpha; ns- not significant.

Following the result of S-W test, resiliency and age exhibited the normal distribution data while gender of household head and household size did not. Thus, Pearson Correlation was used to analyze the relationship of resiliency with age. Meanwhile, Pearson's Chi-square was used to analyze the relationship of resiliency with 
gender, since the variable was nominal scale. Furthermore, Spearman Correlation was used to analyze the relationship of resiliency with household size, which did not follow a normal distribution. To determine the statistical dependence of these variables, the values derived from these analyses were matched with the qualitative responses on correlation presented in Table 10. The result of the correlation analysis for the three independent variables and resiliency are shown in Table 11.

Table 10. Corresponding interpretation of correlation coefficient.

\begin{tabular}{cc}
\hline Correlation Coefficient & Interpretation \\
\hline 1 & Perfectly correlated \\
$0.81-0.99$ & Very strong \\
$0.61-0.80$ & Strong \\
$0.41-0.60$ & Moderately correlated \\
$0.21-0.40$ & Weak \\
$0.10-0.20$ & Very weak \\
0 & No correlation \\
\hline
\end{tabular}

\subsubsection{Resiliency and Age}

The result of the analysis showed that at $5 \%$ level of significance, the p-value of 0.120 was not significant since it was greater than the alpha (Table 11). Hence, age and resiliency were not correlated. Gauging the interpretation in Table 11, the value of variables showed no correlation at all (-0.116), and the correlation was insignificant at 0.05 level. Although age is cited as one of the socio-economic determinants of resiliency in most studies (see for instance Tierney et al. 2001; Heinz Center 2002; National Research Council 2006 as cited by Cutter, et al., 2009;), the finding of this study showed otherwise. This implies that age does not necessarily mean that a person is more resilient as he or she gets older.

\subsubsection{Resiliency and Gender}

In Table 11, the chi-square value of .707 showed that gender was not correlated with resiliency since the p-value is 0.465 , which was greater than the alpha. Gender was cited as a determinant of resilience, however, findings showed otherwise. This means that impacts of disasters were gender neutral and there were no difference in how men and women are affected by, cope and respond to the effects of disasters.

\subsubsection{Resiliency and Household Size}

The result of the analysis showed that at $5 \%$ level of significance, the p-value of 0.003 was significant since it was less than the said alpha (Table 11). Hence, it could be concluded that household size s correlated with resiliency. These variables were weakly correlated positively $(0.221)$, and the correlation was significant at 0.05 level.

The study conducted by Cassidy (2012) indicate that household size determine both the number of connections and the amount of capital that households can accumulate, hence their adaptive capacity. The higher the number of household members who are socially networked are likely to have a wider range of livelihood strategies, greater levels of other forms of social capital, and greater overall capital which could contribute to a more resilient community.

Table 11. Correlation result of resiliency to three independent variables

\begin{tabular}{lccc}
\hline \multicolumn{1}{c}{ Variables } & Correlation Method & P-value & Conclusion \\
\cline { 2 - 4 } & Pearson coefficient & & \\
Resilience and Age & -0.116 & $0.120^{\text {ns }}$ & Not correlated \\
Resilience and Gender & Chi-square & & \\
& 0.707 & $0.465^{\text {ns }}$ & Not correlated \\
Resilience and Household size & Spearman coefficient & & \\
& $0.221^{* *}$ & $0.003^{*}$ & Correlated \\
\hline
\end{tabular}

* significant at $5 \%$ level of alpha; ns- not significant; ** correlation is significant at 0.01 level (2-tailed). 


\subsection{Implications of Assessing Community Resilience to CBFM Program}

CBFM promotes greater participation of upland communities in forest management, which intends to provide them equitable access to forest goods and services, improve forest productivity and promote ecological sustainability (Pulhin, 1996; Pulhin et al., 2007). The assessment of resilience in this study considers CBFM as an adaptive capacity contributing to the community's five capital assets. In terms of social capital, CBFM is awarded to an organized People's Organizations (PO) and is assumed that participation and trust have been built within. For human capital, trainings and skills improvement are basic activities to capacitate and empower the PO. Physical capital includes availability of infrastructure such as farm-to-market road, training hall and other properties and assets. Financial capital is based on livelihood opportunities and natural capital pertains to forest and other resources such as land and water.

The community is expected to have a higher resilience index in terms of social and natural capitals because of CBFM. However, findings show that social and natural capitals have the lowest scores and that problems on facilitation and implementation of the program may be contributory.

The CBFM program in Barangay Maonon, Ligao City aimed to contribute to the improvement of forest cover and farm lands of the community. Contrary to expectations, study results showed low index in terms of natural capital. Damage and loss of crops resulted to low yield coupled with poor access to water sources for farming activities contributed to low natural capital index. Also, unsustainable projects such as reforestation, agroforestry and livelihood activities like livestock raising contributed to the low score.

According to a PO officer, the CBFM program was perceived by its members as just another reforestation project of the government rather than a long-term forest management strategy. Thus, sustainability of interventions in their locality, which could promote sustainable forest management, has been difficult to achieve. Some PO members did not participate in meetings as well as in reforestations and planting activities and lost their trust in the program as they perceived CBFM as projects that use them as hired laborers rather than partners for sustainable forest development. Thus, membership declined from 300 to 75 members as of 2014 .

One of the factors that could have contributed to the improvement of natural capital is awareness and skills enhancement through trainings, seminars and workshops. Enhancing capacity of farmers is utmost importance to enable them to cope with weather-related disasters (Peria et al., 2016). However, limited capacity building and values formation to better appreciate the true vision of CBFM and implement the program accordingly was lacking in the study area. Additional trainings were needed in terms of forestland use planning, financial management and auditing as well as CBFM framework preparation. During this initial phase, community organizers were employed to encourage the community to commit and form the organization. However, the members felt that they were not capacitated enough particularly due to limited awareness and knowledge, lack of leadership and management skills of the PO leaders and officers, and irregularities of meetings. The provision of appropriate trainings and capacity building to members was limited, thereby also affecting the human and social capitals of the community.

In addition, mobility and access to the area limited full financial and technical support, particularly the conduct of monitoring and evaluation activities. Barangay Maonon is one of the farthest barangays from the town proper and that the CBFM coordinator and other concerned staff had difficulties in performing regular monitoring and evaluation activities especially during rainy season.

\section{Conclusion}

Farming is the major income source of the respondents in the community; and is primarily affected when typhoons and other weather-related hazards happen. Hence, farming technology such as the CFV was introduced to address the impacts of disasters such as flooding, landslides and damage to agriculture.

The assessment revealed that CBFM community's resilience to weather-related disaster is low. Typhoon was the major hazard that caused disasters, thereby, affecting various community sectors and the five capitals of the community. Results implied that loss of lives and livelihood as well as destruction of built facilities and houses contribute to the sizeable impacts of typhoon.

Assessing and understanding the five types of community capitals would contribute to the overall knowledge about the general well-being of the community and its resilience. A capital-based approached of framing disaster resilience would be an important tool to convince policy makers support efforts on disaster mitigation, preparedness, responses, and recovery.

In this study, household size were determinants of resiliency while age and gender proved to be not related, in contrast to other literature which cited socio-demographic factors as factors affecting resiliency. The framework 
presented in this study has potential in measuring disaster resilience as a starting point in developing a more concrete and robust methodology in assessing resilience.

Human and natural capitals of the community had the lowest indices based on the analysis of the community's level of resilience to disasters. Thus, in this study area the presence of CBFM did not contribute to the resiliency of the community to weather-related disasters. Although, CBFM remains a promising strategy in improving the adaptive capacity of upland communities because of its governing policies and community-based approach, there is a need to improve facilitation and implementation on the ground. Trust among members as well as between PO and DENR should be well established to improve the welfare of upland communities and increase their adaptive capacity to weather extremes or hazards.

\section{Recommendation}

To increase the adaptive capacity of upland community, institutional support is a necessity. Collaboration among various stakeholders such as the LGUs, DENR, including the POs, should be forged to increase synergy as well as ensure that each of them perform their responsibilities in such programs like CBFM. The government should allow CBFMs to have increased formal involvement in the decision-making process and policy changes that can impact positively on their lives. In addition, strategic interventions at the local level are critical to achieve the social justice and equality, thus addressing the observation in some projects that the community elites and educated are benefiting most (Bacalla, 2006).

There should be additional programs to increase community capacity, particularly those that enhance awareness, skills and competencies. The local government unit has a vital role in facilitating and building resilience of communities. To achieve a responsive disaster risk reduction management, there should be collaboration among various stakeholders. There is also a need for stronger emphasis on building resiliency within the community. This will require not only external support but also the initiative of community members to mobilize and harness their own local resources and capabilities to anticipate, prepare for, and mitigate the adverse impacts of weather-induced disasters. As communities are engaged in the social learning process, facilitation of external organizations such as government or non-government extension workers, empower the community-an important step for building resiliency.

\section{Acknowledgement}

The authors would like to express their sincerest gratitude to the Department of Science and Technology (DOST)-Philippine Council for Agriculture, Aquatic and Natural Resources Research and Development (PCAARRD) for providing scholarship to the main author during her studies.

\section{References}

Adger, W. N. (2000). Social and Ecological Resilience: are they related? Progress in Human Geography, 24, 347-64. Retrieved from http://journals.sagepub.com/doi/abs/10.1191/030913200701540465

Adger, W. N. (2006). Vulnerability. Global environmental change, 16(3), 268-281. https://doi.org/10.1016/ j.gloenvcha.2006.02.006

Agrawal, A. (2008). The Role of Local Institutions in Adaptation to Climate Change. Paper prepared for the Social Dimensions of Climate Change, Social Development Department, The World Bank, Washington DC.

Bacalla, D. T. (2006). Promoting equity: a challenge in the implementation of community-based forest management strategy in the Philippines. Hanging in the balance: equity in community-based natural resource management in Asia, 162-181.

Berkhout, F., Hertin, J., \& Gann, D. M. (2004). Learning to adapt: Organizational adaptation to climate change impacts. Tyndall Centre Working Paper 47. Tyndall Centre for Climate Change Research, University of East Anglia, Norwich, UK.

Brooks, N. (2003). Vulnerability, risk and adaptation: a conceptual framework. Tyndall Centre Working Paper 38. Tyndall Centre for Climate Change Research, University of East Anglia, Norwich, UK.

Buckle, P., Marsh, G., \& Smale, S. (2001). Assessing resilience and vulnerability: Principles, strategies and actions. Victorian Government Publishing Services.

Cassidy, L., \& Barnes, G. D. (2012). Understanding household connectivity and resilience in marginal rural communities through social network analysis in the village of Habu, Botswana. Ecology and Society, 17(4), 11. https://doi.org/10.5751/ES-04963-170411.

City of Ligao. (2000). The Comprehensive Land Use Plan 2000-2004 of the City of Ligao, Albay, Philippines. 
Cutter, S., Burton, C. G., \& Emrich, C. T. (2010). Disaster Resilience Indicators for Benchmarking Baseline Conditions. Journal of Homeland Security and Emergency Management, 7(1). https://doi.org/10.2202/1547 $-7355.1732$

Davidson, M. A. (2006). Designing for disasters. Massachusetts coastal hazards commission, NOAA Coastal Services Center.

Department of Environment and Natural Resources and Philippine Foundation for Environmental Concerns (2008). Community-Based Forest Management Strategic Plan (2008-2017).

Espinas, A. (2013). Geography and Public Planning: Albay and Disaster Risk Management. Human Development Network. Discussion Paper Series. Issue No 4.

H. John Heinz III Center for Science Economics, and the Environment (2002). Human Links to Coastal Disasters. Washington, D.C. Retrieved from H. John Heinz Center.

Harmeling, S. (2009). Global Climate Risk Index 2010: Who is Most Vulnerable? Weather-Related Loss Events Since 1990 and How Copenhagen Needs to Respond. Retrieved January 4, 2010, from www.germanwatch.org

Intergovernmental Panel on Climate Change (IPCC). 2007. Fourth Assessment Report.

Joint Research Centre/Institute for Environment and Sustainability (JRC/IES). (2009). Adaptation and Mitigation Strategies: Supporting European Climate Policy (Project Final Report).

Keim, M. E. (2008). Building Human Resilience: The Role of Public Health Preparedness and Response as an Adaptation to Climate Change. American Journal of Preventive Medicine, 5(35), 508-516. https://doi.org/10.1016/j.amepre.2008.08.022.

Manyena, S. B., (2006). The Concept of Resilience Revisited. Disasters, 30, 434-450. https://doi.org/10.1111/ j.0361-3666.2006.00331.

National Disaster Coordinating Council (NDCC) \& Worldbank. (2005). Natural disaster risk management in the Philippines: Enhancing poverty alleviation through disaster reduction. Worldbank. 83 pp.

National Disaster Risk Reduction \& Management Center (NDRRMC). (2013). Situation Reports on the Effects of Yolanda Typhoon. Official Gazette of the Philippine Government. World Wide Web. Retrieved April 1, 2014 from http://www.gov.ph/crisis-response/updates-typhoon-yolanda

National Research Council (NRC). (2006). Facing Hazards and Disasters: Understanding Human Dimensions. Washington, DC: National Academy Press.

Olsson, P., \& Folke, C. (2001). Local ecological knowledge and institutional dynamics for ecosystem management: a study of Lake Racken Watershed, Sweden. Ecosystems, 4(2), 85-104. https://doi.org/10. 1007/s100210000061.

Peras, R. J. J., Pulhin, J. M., Lasco, R. D., Cruz, R. V. O., \& Pulhin, F. B. (2008). Climate Variability and Extremes in the Pantabangan-Carranglan Watershed, Philippines: Assessment of Impacts and Adaptation Practices. Journal of Environmental Science and Management, 11(2),14-31.

Peria, A. S., Pulhin, J. M., Tapia, M. A., Predo, C. D., Peras, R. J. J., Evangelista, R. J. P., Lasco, R. D., Pulhin, F. B. (2016). Knowledge, Risk Attitudes and Perceptions on Extreme Weather Events of Smallholder Farmers in Ligao City, Albay, Bicol, Philippines. Journal of Environmental Science and Management Special Issue, 31-41.

Pulhin, J. M. (1996). Community Forestry: Paradoxes and Perspectives in Development Practice. PhD Dissertation. The Australian National University, Canberra, Australia.

Pulhin, J. M., \& Dressler, W. H. (2009). People, Power and Timber: The Politics of Community-Based Forest Management. Journal of Environmental Management, 91, 206-214.

Pulhin, J. M., Inoue, M., \& Enters, T. (2007). Three Decades of Community-Based Forest Management in the Philippines: Emerging Lessons for Sustainable and Equitable Forest Management. International Forestry Review, 19(4), 865-883.

Pulhin, J. M., Peras, R. J. J., Cruz, R. V. O, Lasco, R. D., Pulhin, F. B., \& Tapia, M. A. (2004). Vulnerability of Communities to Climate Variability and Extremes: Pantabangan-Carranglan Watershed in the Philippines. AIACC Working Papers No. 44. October 2004.

Putnam, R. D. (1995). Tuning In, Tuning Out: The Strange Disappearance of Social Capital in America. Political Science and Politics, 28(4), 664-683. 
Rebugio, L. L. (2010). Promoting Sustainable Forest Management through Community Forestry in the Philippines. IUFRO-WFSE.

Regional Development Council [RDC]. (2016). Bicol Region Development Plan 2011-2016. Legazpi, Albay, Philippines.

Smith, R., Simard, C., \& Sharpe, A. (2001). A Proposed Approach to Environment and Sustainable Development Indicators Based on Capital. The National Round Table on the Environment and the Economy's Environment and Sustainable Development Indicators Initiative.

Tapia, M. A., Pulhin, J. M., \& Peras, R. J. J. (2014). Vulnerability and adaptation to climate change of selected Community-based Forest Management areas in Oas, Albay, Philippines. Asia Life Sciences, 23(2), 567-592.

Tierney, K. (2009). Disaster Response: Research Findings and Their Implications for Resilience Measures. CARRI Research Report 6. Oak Ridge: Community and Regional Resilience Institute.

Uy, N., Takeuchi, Y., \& R. Shaw, R. (2011). Local adaptation for livelihood resilience in Albay, Philippines. Environmental Hazards, 10(2), 139-153. https://doi.org/10.1080/17477891.2011.579338.

World Resources Institute (WRI) in collaboration with United Nations Development Programme, United Nations Environment Programme, and World Bank. (2008). World Resources 2008: Roots of Resilience-Growing the Wealth of the Poor. Washington, DC: WRI.

\section{Copyrights}

Copyright for this article is retained by the author(s), with first publication rights granted to the journal.

This is an open-access article distributed under the terms and conditions of the Creative Commons Attribution license (http://creativecommons.org/licenses/by/4.0/). 